Manuscript title: Nature as a Subject of Rights? National Discourses on Ecuador's

Constitutional Rights of Nature

Author and institutional affiliation: Synneva Geithus Laastad, Department of Sociology and Human Geography, University of Oslo

Note on Contributor: Synneva Geithus Laastad is a PhD Candidate in Human Geography at the Department of Sociology and Human Geography at the University of Oslo, Norway, currently researching discursive and spatial effects of oil extraction in the Ecuadorian and Peruvian Amazon.

Acknowledgments: The author wishes to thank Associate Professor Jemima García-Godos and two anonymous reviewers whose insightful feedback greatly improved and clarified this article, and all informants for sharing their knowledge and opinions. All omissions are my own.

Contact info: s.g.laastad@sosgeo.uio.no

Word count (excluding abstract and references): 9728 


\section{Nature as a Subject of Rights? National Discourses on Ecuador's Constitutional Rights of Nature}

In 2008 Ecuador became the first country in the world to make nature a subject of constitutional rights, and they did so by invoking nature as la Pachamama, the Kichwa Mother Earth deity. This is a biocentric notion which challenges the modernist vision of nature as resources subject to human use, which could imply a fundamental transition in the human-nature relationship with implications far beyond the legal system. With this point of departure, the aim of this article is to explore how Ecuador's rights of nature are understood and employed rhetorically by relevant actors, particularly in relation to the country's development model, which is based on extraction and export of natural resources, i.e. a subject understanding of nature. The rights of nature's meaning has been attempted fixed in a discursive struggle, and three different discourses regarding the rights of nature have been identified from interview data: The Anti-Capitalist Ecologist Discourse, the Transformative Discourse and the Anthropocentric Developmentalist Discourse. The latter, which conceptualizes the rights of nature as anthropocentric sustainable development has become hegemonic. This can explain why the rights of nature can co-exist alongside continued and increased resource extraction with detrimental socio-environmental effects.

Keywords: Ecuador, discourse, rights of nature, natural resources, development 


\section{Introduction}

When the Ecuadorian people ratified their current (and twentieth) constitution in 2008, Ecuador became the first country in the world to provide nature with intrinsic rights. Chapter Seven of the Ecuadorian Constitution states that

Nature, or Pacha Mama, where life is reproduced and occurs, has the right to integral respect for its existence and for the maintenance of its life cycles, structure, functions and evolutionary processes

(República del Ecuador, 2008, unpaged)

Up until this moment nature had never before been represented as a right-bearing entity, given value simply as a product of its existence. This biocentric foundation is different from the anthropocentric notion of humans' right to a healthy environment. Nature is moreover represented as Pachamama, the Mother Earth deity in Kichwa, the largest indigenous minority language in Ecuador. This can have a myriad of implications. It can imply that a sort of being - nature - mythological yet tangible, is placed into a system that has previously only understood it as a sum of its parts, i.e. as natural resources. It can imply an institutionalization of a notion of interconnectedness and interdependence between all elements of nature, including humans. It can imply that nature must be seen as a living being, not an inert objectified one.

Conceptualizing nature as a subject with rights could imply a change in the humannature relationship from one between a subject with agency and an inert exploitable object, to a relationship between subjects that both require respect and tolerance. Their meaning thus extends far beyond the legal sphere. The rights of nature are therefore overdetermined, i.e. containing a surplus of meaning (Laclau and Mouffe, 2014).

There are several studies presenting in-depth analyses of how the rights of nature came to be incorporated into the Constitution, through different processes in the Constituent Assembly (e.g. Akchurin, 2015; Espinosa, 2015; Kotzé and Calzadilla, 2017; Tanasescu, 2013). The point of departure of this article is that the meaning of the rights of nature was not solidified with their incorporation into the Constitution. On the contrary, the very act of making them constitutional increased their overdetermination, allowing for the development of different discourses on the rights of nature. 
The legal implementation of the rights of nature have been analysed (Kauffman and Martin, 2017), and the evolving strategies of the Ecuadorian environmental movement (Lewis, 2016). There has also been multiple studies analysing Ecuador's natural resource politics post-2008 (e.g. Bebbington, 2012; Crabtree and Crabtree-Condor, 2012; Moore and Velásquez, 2012; Villalba-Eguiluz and Etxano, 2017). Lalander and Merimaa (2018) presents an analysis of Ecuadorian discourses on environmental conflict in general, where the rights of nature serve as an important contextual factor. This study builds on these analyses by providing the first issue-specific discourse analysis regarding the Ecuadorian rights of nature specifically.

The analysis is guided by two research questions: 'Which are the different discourses on the rights of nature in Ecuador, and how are these constructed?' and 'How has the power relations between them changed over time?' The first research question is answered in the main part of the analysis, which presents the three different discourses found on the rights of nature in interview data: the Anti-Capitalist Ecologist Discourse, the Transformative Discourse and the Anthropocentric Developmentalist Discourse. These are deconstructed to present their constitutive elements, through both direct quotes and synthesizing of informants' articulations. The second part of the analysis answers the second research question. Here, the increasing hegemony of the Anthropocentric Developmentalist Discourse is explained by a self-fulfilling cycle created by mutually enforcing constraints stemming from both discursive and non-discursive factors, limiting the discursive opportunity space for the other two more disruptive discourses. Its hegemony explains why the rights of nature can co-exist alongside continued and increased resource extraction with detrimental socio-environmental effects, as the solidified signification of the rights of nature is now anthropocentric sustainable development, of less importance than continued economic growth.

The next section outlines the development leading up to the implementation of the rights of nature, emphasising the 2007-2008 Constituent Assembly's unique receptiveness to new ideas. It then goes on to discuss the contradictory Constitution, and what it might entail for the official understanding of the human-nature relationship. Next, the methodological assumptions of the analysis are presented, and the research design. The main part of the analysis is the presentation of the three different discourses, and their evolving power relations. A discussion of the reasons for and the outcomes of an increasingly hegemonic Anthropocentric Developmentalist Discourse concludes the article. 


\section{Ecuador and its Contradictory Constitution}

The former Ecuadorian President Rafael Correa gained his first presidential election in 2006, running as the leader of the anti-systemic political alliance Alianza PAÍS. Alianza PAÍS initially included many voices, both environmentalists, indigenous and participatory and centralist and developmentalist (Novo, 2014). Correa went on to win the subsequent election in 2009, and the following one in 2013. In 2017 his former Vice President Lenín Moreno gained the presidency, running for the same political alliance. ${ }^{1}$ Commenting on his first victory, Correa stated that it was not just another election, 'but a true historical change, a new history has begun, a new homeland has begun' (Correa 2006, quoted in Conaghan, 2011, p. 260).

Alianza PAÍS' political programme was named the 'Citizens' Revolution'. Andrade and Hopp (2015, p. 92) define this as 'a state-run programme of rapid economic change under a socio-political process of transformation'. It emphasised individual social rights, and included high public spending on social programmes, infrastructure and education. The Citizens' Revolution also included a new development model based on the indigenous notion of Buen Vivir, good living. There is no one definition of the term, but it is often argued to be about living well instead of always living better (Lalander, 2014). Radcliffe (2011) argues that Buen Vivir has been formulated to be in discursive opposition to 'Western' and neoliberal development, and is presented as a paradigm unique and appropriate to Ecuador.

This rhetoric of rupture and new beginnings was underscored by Correa's first act as president, which was to call for a referendum on a constituent assembly, as a new constitution would be the main vehicle for instituting promised changes (Tanasescu, 2013). The Constitutive Assembly was characterized by a highly receptive climate and an openness towards new ideas, stemming from the notion that Correa's victory represented a new beginning for the country (Gudynas, 2009). The drafting of the new Constitution was a highly participatory process, with citizen consultations throughout the country as well as in the city of Montecristi, the seat of the Constituent Assembly. Civil society actors flocked to Montecristi to present their causes and attempt to influence Assembly members. In the eight months the Constituent Assembly had available to draft a new constitution, it received over three thousand suggestions from civil society.

\footnotetext{
${ }^{1}$ Moreno and Correa have since turned bitter political opponents, and Correa and his followers were forced to leave Alianza PAÍS in January 2018.
} 
There are four main explanatory factors for the incorporation of the rights of nature into the final draft of the Constitution: The unique timing provided by a Constituent Assembly tasked with creating the blueprint for a new Ecuadorian society; the prior struggle of the environmental movement elevating environmental issues to the national-level, not least regarding destructive socio-environmental effects of oil extraction in the Ecuadorian Amazon; the presence and power of the indigenous movement and the work of key activist actors with an international network. The indigenous movement was not an initial proponent of the rights of nature, as their main concern at the Constituent Assembly was to ensure that Ecuador would be defined as a plurinational state. The openness to concepts stemming from indigenous cosmologies by the representatives to the Assembly did however permit them to think conceptually about nature-society relations (Espinosa, 2015).

The rights of nature do not represent a 'pro forma recognition of widely accepted rights' (Akchurin, 2015, p. 960). They had to be actively constructed. Environmental lawyers and activists with an international network from the Ecuadorian NGO Fundación Pachamama engaged a US NGO, the Community Environmental Legal Defense Fund (CELDF) to present the idea in workshops at the Constituent Assembly. They had expertise from years of scholarly debate and development of the concept in an international network of legal scholars, and incorporated this into the Ecuadorian context, e.g. by representing nature as the Pachamama (Espinosa, 2015).

The President of the Constituent Assembly and former close ally of Correa, Alberto Acosta, was a staunch proponent of the rights of nature, alongside his main advisor, Esperanza Martinez from the radical NGO Acción Ecológica. A month before the deadline Acosta resigned over pressure from the executive to speed up the process (e.g. El Universo, 2008). The final draft was finished in a hurry, and the rights of nature were included. That the country had given nature intrinsic rights was characterised by two of the informants from the non-profit sector as a surprise resulting from a quick process (Granizo, interview 18.08.2015; Hernandez, interview 11.08.2015).

Espinosa understands the incorporation of the rights of nature as due to 'interpretive affinities'. She argues that such affinities 'among the interpretive repertoires of rights of nature advocates and indigenous and environmental movements shaped and enabled the advocacy for rights of nature'. The rights of nature were 'stitched onto a discursive context imprinted with nationalist feelings underpinning a critique of neo-liberalism, and aspirations for legal progress and the decolonization of society' (Espinosa, 2015, p. 1). They were as such 
able to 'make sense' to several different discourses, and resonate with indigenous cosmology, a critique of neo-liberal development and environmental struggles (Tanasescu, 2013).

The bridging of different 'schemas' (Akchurin, 2015), 'interpretive repertoires' (Espinosa, 2015) or discourses meant that the rights of nature could be accepted by a majority of representatives in the Constituent Assembly. It alleviated some immediate tensions between the rights of nature and the traditional anthropocentric legal discourses representing nature as resource or property (Akchurin, 2015). The rights of nature did however cause increased tensions between civil society and the state after the Constitution was approved in 2008 , in the context of several state-led large-scale oil and mining projects (Kauffman \& Martin, 2017).

No contextual analysis of the rights of nature can be complete without an understanding of Ecuador's dependency on extraction and export of natural resources. Ecuador's top ten export articles are all natural resources (including foods), accounting for 88.5 per cent of total value of exports (IMF, 2017). Oil accounts for over half of Ecuador's export earnings, and approximately twenty-five per cent of public sector revenues (U.S. Energy Information Administration, 2017). The country has the third-largest oil reserves in South America, most of which is located in its Amazon region, with almost half of its estimated reserves located in the Ishpingo-Tambococha-Tiputini (ITT) blocks in the Yasuní national park. This is one of the most biologically diverse areas in the world and home to two indigenous cultures living in voluntary isolation (Larrea and Warnars, 2009). In this context it is clear that making nature a subject of rights could have enormous implications.

That their meaning extends beyond the legal space is also argued in other analyses. Akchurin (2015) argues that the incorporation of these rights allowed for 'broader ontological debates about the status of nature' (p. 961), as it implied 'a profound shift in the way the proper ethical relationships between nature and people would be described in the constitution' (p. 951). Kotzé and Calzadilla (2017, p. 425) state that the Constitution 'entrenches and exacerbates both a normative and an ethical conflict between anthropocentrism and ecocentrism at the highest possible juridical level'.

Sánchez-Parga claims that the rights of nature have a 'seductive semantic' (2014, p. 94, author's translation). Due to their novelty, their vague definition and limited application, actors can fill the rights of nature with meaning according to their worldviews and political agenda. This article therefore argues that the rights of nature have produced new and hybrid discourses, as their incorporation into the constitution exacerbated their overdetermination, 
rather than solidifying their meaning. The inherent tensions caused by these rights' uneasy incorporation into a legal-political system based on nature as subject to human use have been crystallized into different discourses.

\section{The Rights of Nature as Discourse}

Discourses try to fix meaning, this way defining which constructions of the social world can be taken for common truths, and therefore condition social processes and actions (Neumann, 2001). Discourses are constantly being articulated, and can therefore never be totally closed or complete. Their exterior limits are created by other discourses that are also inherently openended. This unstable nature of discourses allows for change and adjustments (Doty, 1996). As meaning is transitory, and therefore changeable depending on culturally and historically specific social interaction, it must be possible to deconstruct representations of reality, to take them apart to reveal their subjectively constructed foundations. This deconstruction is the discourse analysis.

This analysis of the rights of nature is based on the Critical Discourse Analysis framework (Fairclough, 2010). In this framework, discourse is understood as one system mutually constituting and being constituted by other systems operating by different logics, in a dialectic relationship. It is important to state that a discourse analysis does not uncover an underlying truth. It is the study of specific and subjective understandings of the world, that are nonetheless constitutive of the social world as they condition thought and action (Jørgensen and Phillips, 2002).

Fairclough (2003) states that there are two types of causal powers shaping discourse: social structures and practices, and social agents. Social agents will be constrained by these structures and practices, but their agency will not be totally determined. An analysis of the economic, social and material factors influencing and constraining the understanding and possible application of the rights of nature, is outside the scope of this article. Their existence is nonetheless recognized and they are treated as social structures and practices shaping the discursive opportunity structure that regulate actors' articulations. A clear example is Ecuador's economic dependence on oil. This opportunity structure regulates the discursive repertoire actors will draw on, both as 'honest' expressions and as pragmatic rhetoric to achieve desired political goals.

The unit of analysis are national-level discourses on the rights of nature and their implications for natural resource extraction as a basis for development model. Discourse is an 
intermediate unit of analysis between the text itself and its social context. This implies that the analysis of discourse is concerned with the 'external' relations of text with other elements of social practices and structures, and not 'internal' relations such as grammar and linguistics (Fairclough, 2003). The tools for analyzing the discourses on the rights of nature have been adopted from Dryzek's (2013) analysis of environmental discourses, as they are suitable to the level of analysis. In his analyses, Dryzek searches for four elements that together constitute a discourse. These are a discourse's ontology, assumptions about natural relationships, agents and their motives and metaphors and other rhetorical devices.

Dryzek's environmental discourse analysis is useful for demonstrating the variety of complementing and competing discourses existing within a certain order of discourse, i.e. all the discourses that struggle to define a certain field (Fairclough, 2016). It nonetheless lacks a strong emphasis on power and hegemony. Concepts from Laclau and Mouffe's discourse theory is therefore incorporated into the second part of the analysis. In this theoretical approach discourse is defined as 'systems of meaningful practice' (Stavrakakis et.al., 2000, p. 3 ), consisting of both objects and practices. Discourses try to fix surplus meaning into stable structures through articulation. In an overdetermined field where many different discourses could possibly become constitutive of social reality, the discourse that fixes meaning through stable articulatory structures becomes hegemonic. Neither absolute fixity nor absolute nonfixity is possible however, and a hegemonic discourse is an unstable structure. It will always contain subverting elements, and this is an inherent antagonism that can challenge a hegemonic discourse (Laclau and Mouffe, 2014). This analysis does not adhere to the totalizing ontology of this theory, but its concepts are nonetheless useful to explain the increasing hegemony of the Anthropocentric Developmentalist Discourse, a process reducing the rights of nature to anthropocentric sustainable development, and simultaneously decreasing the influence of competing discourses.

To examine how the rights of nature are understood and articulated by key actors, twenty-two semi-structured interviews were carried out in Ecuador in August and September 2015. The interview sample consists of actors from government, civil society, academia and extractive industries, including some of the key actors in the development and instigation of the rights of nature. The transcribed interviews were deconstructed through applying Dryzek's discourse analytical tools, allowing for an identification of patterns and ultimately discourses. The second part of this analysis additionally builds on a comparison of the sections concerning the rights of nature in the National Development Plan 2013-2017 (Senplades, 
2013b) and 2017-2021 (Senplades, 2017), as they illustrate the increased political influence of the Anthropocentric Developmentalist Discourse over time.

Qualitative research in general and an interpretive methodology in particular is a subjective endeavour, and transparency is a requisite for rigour (Hay, 2010). It is important to state that the interview sample is not exhaustive. Although it is a strategic sample attempting to include the most important voices in the field, a larger sample would have brought further nuance into the analysis (Silverman, 2010). Government documents, official websites of informants' organizations, and articles and books written on the subject of the rights of nature do demonstrate the same discourses and patterns presented below however, which adds to the reliability of the analysis (e.g. Acción Ecologica, 2012; Acosta, 2011; Ávila, 2011; Fundación Pachamama, 2010; Melo, 2009; Senplades, 2013b, 2017). The patterns identified in this analysis cannot however be used to argue that no indigenous actors articulate the Anthropocentric Developmentalist Discourse, or that no government actors articulate the Anti-Capitalist Ecologist Discourse, although this is found to be the case here. It is the discourses in themselves that are the unit of analysis, not the actors articulating them. The aim of discourse analyses is not generalizability, but to provide a convincing interpretation of the why and the how of processes pertaining to the social world, where discourse is one important causal factor.

This analysis builds on the same understanding of the contradictory context as presented by Lalander and Merimaa in their analysis of Ecuadorian environmental discourses (2018): that the actors rely on the shared premises of progressing from a neoliberal system, that extraction is undesirable in itself and that an indigenous worldview is a source for sustainability. Several scholars have presented analyses on the related and overlapping order of discourse of Buen Vivir, and three different discursive streams have been presented. These are the indigenous/culturalist, the ecologist/post-developmentalist and the socialiststatist/Eco-Marxist (Cubillo-Guevara and Hidalgo-Capitán, 2015; Lalander and Cuestas-Caza, 2017; Le Quang and Vercoutère, 2013; Villalba-Eguiluz and Etxano, 2017). Although containing commonalities, the discourses identified on the rights of nature specifically, transverse these categories. The Ecologist Anti-Capitalist Discourse has a strong indigenous foundation, but its main feature is nonetheless anti-capitalism. It shares an aim of moving towards a more biocentric co-existence with nature with the Transformative Discourse, yet the emphases of these two discourses differ a great deal. The Anthropocentric Developmentalist Discourse is the most similar to the Socialist-Statist understanding of Buen Vivir. As it is important to underline its anthropocentric representations of the rights of nature and how 
these are constructed specifically, and the Socialist aspect is underplayed on the topic of the rights of nature, it is in this context given a more issue-specific name.

Below the three identified discourses are presented according to the overarching features of each discourse. ${ }^{2}$ Some informants employ a hybrid discourse, mixing characteristics from either the Anti-Capitalist Ecologist Discourse and Transformative Discourse, or the Transformative and Anthropocentric Developmentalist Discourse. These have some overlap, and the discourses could be visualized as on a continuum, with the AntiCapitalist Ecologist Discourse and the Anthropocentric Developmentalist Discourse on either side of the Transformative Discourse.

\section{The Anti-Capitalist Ecologist Discourse}

It is within the Anti-Capitalist Ecologist Discourse that the representation of nature as Mother Earth is articulated most directly. All her components are deemed to deserve rights, and it is therefore akin to ecologism, rather than the more anthropocentric founded environmentalism (Dobson, 2000). This is merged with a strong anti-capitalist feature. Capitalism, and its ontological foundation in Western modernity, is seen as the main culprit for continued environmental degradation. The informants articulating this discourse are from the indigenous movement, and environmental NGOs sympathetic to their cause.

The solution to an environmental and societal crisis caused by capitalist exploitation of nature is portrayed as a return to a community existence based on an understanding of nature as an interconnected whole, where everything is interrelated and interdependent. This discourse therefore mixes a more mainstream critique of capitalism with a positive view of traditional, indigenous ways of life. Below I elaborate on its main features.

\section{Mother Earth as an Interconnected Whole}

It is within this discourse that concepts stemming from an indigenous worldview are most strongly articulated. This analysis does not deliberate on whether this is actually due to informants having a different ontological foundation, or if it is merely expected argumentation within a broader discursive strategy linked to identity politics. Everything that makes up nature, including plants, rivers, winds, soil and so on, is seen as live beings, and several informants stated that nature should have rights simply because it is alive, the same way we are. The arguments for the rights of nature are therefore not complicated, but straightforward and immediate, providing nature with rights is almost seen as obvious. This is articulated by

\footnotetext{
${ }^{2}$ Full transcripts in Spanish are available upon request
} 
Luis Yanza, co-founder of the Amazon Defence Front and prominent environmental activist who argues that nature consists of

elements that also have life, like human beings. [...] And if these elements have life, why should we deny them rights, just like us human beings have life.

(interview 01.09.2015)

The same point is made by indigenous academic and activist Luis Fernando Sarango, who states that

[nature] as seen from capitalism, seen from a Western paradigm, is an inert being.

But for us it is not an inert being, it is a living being. Because it has movement, it has energy.

(interview, 05.08.2015)

\section{The Rights of Nature as Anti-Capitalist}

The Anti-Capitalist Ecologist Discourse takes for granted that an indigenous ontology based on respect and a relational relationship with nature leads to harmony and balance. It logically follows that environmental problems stem from the dualist modern ontology where humans and nature are separated and seen as opposite, allowing man to exploit nature. This was argued by Sarango, who narrated the story of our civilization in the following way:

It turns out that the paradigm of Western civilization many years ago, thousands of years ago separated, disconnected totally from nature. To choose itself as the centre of the world $[\ldots]$ So they transformed nature into an object.

(interview, 05.08.2015)

The same informant goes on to exclaim that

Capitalism, trying to respect Mother Earth? Forget it. How can it respect it? Because everyone is struggling to survive.

This dualist ontology and the capitalist representation of nature as resources for human use are taken to be the overarching problem. Therefore, the rights of nature is more than just environmental legislation, it presupposes more systemic changes. Humberto Cholango, former leader of the national indigenous movement and current Minister of Water, argued that obviously this concept is not just an ecological concept, it is not a concept to think about the defence of the Mother Earth and nothing more, but it is a concept of struggle against 
capitalism, struggle against the neoliberal model, that preys on and impoverishes the societies of the world.

(interview, 25.08.2015)

\section{Oil Extraction Necessary for a Dependent Country}

As Ecuador plays by the logic of an international capitalist economy, oil extraction is understood as necessary at the moment, but unwanted in the long term. Extractive activity should be strictly regulated, and the extractive frontiers should not be expanded. There should also be a clear aim of diversifying the economy. The articulators of the Anti-Capitalist Ecologist Discourse understand that this is challenging however. Esperanza Martinez, explains that

it is hard, because we are in a globalized model, in a hegemonic economic system, and it is very difficult to change a model within a country, a country as small as Ecuador, when it is within a superior model, which forces it to apply this model.

(interview, 12.08.2015)

Nonetheless, the informants articulating this discourse emphasize the detrimental effects and the suffering that oil extraction has led to for the communities closest to extraction sites. Yanza argues that 'for those of us who live there [...] there is no Buen Vivir' (interview, 01.09.2015). He goes on to argue that the state's idea of Buen Vivir includes great infrastructure projects in the rainforest, and that it is therefore a colonialist vision, a vision of development seen from capitalism, i.e. the concept of Buen Vivir is co-opted.

It is also pointed out that Ecuador is an underdeveloped country; 'a dependent country, and now we are more in debt than ever, and therefore they have to find a way to have the money to pay these debts'

(Sarango, interview 05.08.2015)

Categorising their country as underdeveloped functions as an explanatory factor for its oil dependency. The Anti-Capitalist Ecologist Discourse is critical towards the state, but it also sees the state's agency to substantially change the economic system as limited by the international economy. The view on the state is therefore highly contradictory, providing an interesting tension within the discourse. 
Ecuador is represented as dependent in two ways: as an underdeveloped and indebted country in a subject position to richer, developed countries, and as a result from this: dependent on oil extraction. This is in line with dependency theory, here Ecuador is represented as a 'periphery' country dependent on 'core' countries buying their commodities. According to proponents of dependency theory, the solution to perpetual underdevelopment is to look inwards and nurture national industry, through import substitution industrialisation (ISI) (Payne and Phillips, 2010). This is not a factor in the Anti-Capitalist Ecologist Discourse. Its articulators might be inspired by dependency theory, but they do not discuss industrial policies, solutions are instead provided on a more overarching level as a transformed relation between humans and nature.

\section{The Rights of Nature as an Instrument for Continuous Struggle}

The metaphor of 'struggle' or 'to fight' (lucha/luchar) is repeated numerous times within this discourse. The rights of nature are represented as a culmination of indigenous struggle and their identity politics. They see the separation of man and nature as originating from colonialism, and their struggle for recognition that they are a different people with different worldviews as directly related to the incorporation of the rights of nature in the 2008 Constitution. A sense of continuity is therefore apparent, underpinning the notion that a return to the original societal organisation of indigenous nationalities is a solution to environmental crises today. This component of the discourse is in line with Espinosa's (2015) and Tanasescu's (2013) argument that the rights of nature were stitched into a context in a way which made them resonate with different existing discourses, including that of indigenous identity politics.

The fact that the rights of nature are now a part of the Constitution is also represented as an 'inspiration or instrument for Ecuadorians to struggle for these rights to be respected' (Yanza, interview 01.09.2015). Informants say that there is a great deal of resistance to extractive activities in Ecuador today, and that the rights of nature should be deployed by everyone opposing extractive projects. This was summed up by Sarango who states that 'we are using the rights of the Mother Earth even just to shout' (interview, 05.08.2015).

Another struggle mentioned to a great extent is the endeavour to raise awareness. A societal transformation has to be pushed from the bottom-up, and a first step is to change attitudes. They emphasize the need to educate and make people understand the importance of taking care of nature, aiming for a more harmonious co-existence with it, instead of a consumerist lifestyle accumulating material goods. Repeatedly, this is seen as a process that 
will take years, and it is hoped that providing nature with rights is something that will have an effect, but in the medium and long term.

\section{The Transformative Discourse}

The second discourse has been named Transformative. The informants articulating this discourse are mostly from the non-profit and academic sector. They express the idea that the rights of nature can represent the first step from an anthropocentric way of organising our societies, towards a more biocentric co-existence with nature. This argument is associated with the post-developmentalist discourse presented in inter alia Le Quang and Vercoutère's analysis of discourses on Ecuador's development model (2013). Another main feature of the Transformative Discourse is however its international outlook. Particularly climate change is used as an argument for why our current way of existing needs to change on a global level, and how the rights of nature can contribute in this direction. They use strong rhetorical devices such as likening the provision of rights to nature to that of giving rights to AfricanAmerican slaves, and state that we are at a revolutionary point in history.

The articulators of the Transformative Discourse lament the lack of implementation of the rights of nature by the government, but highlight that the rights of nature have had a greater impact socially, on a cognitive level. This argument is also found to a certain extent in the Anti-Capitalist Ecologist Discourse, but is argued even stronger here.

\section{All Living Elements as Deserving Rights}

When asked about why nature should have rights, the argumentation is similar to that found in the Anti-Capitalist Ecologist Discourse. Essentially, the elements of nature have life, and therefore they should be respected. Their wellbeing matters, and they deserve rights that can protect them. It was stated that 'nature is the expression of life on Earth' and that it is 'an ethical question'. Although the argument in itself is the same as what is found in the previous discourse, it is framed slightly differently. The informants have carried out an ethical deliberation and come to the conclusion that certain aspects of an indigenous worldview make sense, also when linked to what modern science knows about ecosystems and interdependence. Their standpoints are more intellectual than spiritual.

While trying to emphasize how nature is a whole encompassing many live elements, I find that some informants are unable to escape a dualist modernist framework, still seeing nature as something other than, and outside of, themselves. Patricio Benalcázar, Associate of human rights and the rights of nature at the Office of the Ombudsman stated that Earth 'is a being that allows, if there is a harmonious relationship with it, the life of others' (interview, 
08.09.2015). Alberto Acosta, former Minister of Energy and Mines and President of the Constituent Assembly argues that 'we cannot live without nature. Nature can continue to exist without humans' (interview, 20.08.2015).

They are aware of their own identities however. Law professor Ramiro Ávila says that 'I do not have spiritual ties to the Earth [...] but let us say that I have a relationship of respect' (interview, 07.08.2015). He therefore argues that the rights of nature are not necessarily linked to an indigenous worldview. Dania Quirola, former advisor to the Presidency of the Constituent Assembly insists that the importance of the rights of nature is that they recognize a relational system within a biosphere, and that the spiritual side of it is less important, saying that we can call this biosphere 'la Pachamama, Mother Earth or just the third planet from the sun' (interview, 08.09.2015).

\section{The Rights of Nature as a Transformative Solution}

A characteristic of this discourse is that the rights of nature and what they might imply is placed within an international context, where the global community is at a point where we have to change our ways radically, if not by will then by force, due to looming environmental threats. Informants repeat that we are at a dramatic point, a threshold or a limit. Major transformations need to occur, and there is no time to lose. Mario Melo, law professor and former activist in the now closed down NGO Fundación Pachamama expresses that 'we are now at a radical point, of no return'. He goes on to say that it is an 'immediate imperative', to change our ways and start to understand wellbeing as high levels of harmony between individuals and communities, nationalities and nations, instead of the pursuit of economic growth from unsustainable activities and increased purchasing power (interview, 07.08.2015).

The rights of nature can be the instrument for this change; Patricio Hernandez, environmental lawyer at ECOLEX states that now that nature is a subject, we have an obligation to relate to it in a different way. He goes as far as to argue that the rights of nature can mean a 'civilizational change', as the existence of the rights of nature means to exit an anthropocentric framework where the human being is the centre and recipient of everything, and move on to a biocentric system where what is important is life itself (interview, 11.08.2015).

The international situation of an impending climate crisis is used as an argument for why people will need to think about nature differently, more aligned with the idea of it as a right-bearing entity. Hernandez argues that 
it is enough to realize what is going on right now in the international environment, the problems with climate change and the rest to see that we are at the limit, right?

(interview, 11.08.2015)

This was echoed by Melo, who in the context of climate change says that 'it will be because we decide to, or by force, but we will have to respect nature' (interview, 07.08.16). Benalcázar, Associate at the Ombudsman Office goes on to say that

I do not think much time will have to pass before a planetary consciousness will be adapted regarding that what surrounds us is more than things, more than simple resources.

(interview, 08.09.2015)

This transformative and visionary interpretation of the rights of nature culminates in the most prevalent metaphors of this discourse. It is repeated that every conquest of rights is a difficult process, and a development that previously would have been unthinkable. My informants mention the provision of rights to women, slaves and indigenous peoples as examples. This analogy has several aspects, it is also argued that the relationship between humans and nature is similar to the relationship in the Nineteenth Century between the white man and the African-American, and that extractive activities can be compared to slavery, because nature is considered an object, which is exploited. In addition to likening the rights of nature to the abolition of slavery, the sense that this is an historic moment is further accentuated by Hernandez, who argues that because we are at a moment in time where something has to change, we are at a point similar to the period of the American and the French revolutions, i.e. at a breaking point where something has to happen (interview, 11.08.2015).

\section{Varying Effects of a Contradictory Constitution}

The lack of implementation of the rights of nature is lamented. The environmental legislation of the country, executed by the Ministry of Environment, is seen to be regulation that would be in place regardless of the existence of the rights of nature or not. The absence of furtherreaching consequences is understood in relation to the economic development model of the Ecuadorian government. Informants agree that a development model based on intense extractive activities is not compatible with the rights of nature, and it serves as evidence that they have had very limited practical political impact.

Despite being critical of the government's economic model and its extractive policies, the articulators of the Transformative Discourse do see oil extraction as a bare necessity for 
the country for the time being. They agree that oil extraction is not compatible with the rights of nature, because it disrupts natural processes. They do however recognize the need to be realistic about Ecuador's oil dependency. Acosta describes it as a 'bad thing we cannot get out of immediately' (interview, 20.08.2015). The informants nonetheless argue that a decision should be made to change this, there should be active planning towards a diversification of the economy moving away from the current economic model in the medium-term. In addition, they are against the expansion of the frontier of extractive activity, as they are very aware of the detrimental effects oil extraction has on the surrounding areas, both environmentally and socially.

Melo argues that the problem is not oil extraction in itself, it is the economic model defined as extractivism, retaining extractive activity as the main source for economic growth. He reasons that

the problem with extractivism is not whether there is oil extracting activity or not. There can be. The problem is to base all hope of development, growth, prosperity, on this activity, or on mining.

He likens oil extraction to a magic act, which is to

absolve the wealth from the soil, convert it into money, and this money goes to international markets and capitals.

(interview, 07.08.2015)

What stays behind he says, is waste, pollution and violence. What these informants agree upon is that they have no clear answer to how Ecuador can change from a development model based on the extraction of natural resources, but that it is necessary to find one. An answer should therefore be looked for with the highest priority.

\section{The Rights of Nature as an Instrument for Awareness Raising}

Despite sharing a somewhat bleak outlook on the economic and political effects of the rights of nature, the informants that articulate the Transformative Discourse are more positive when it comes to the social impacts of the rights of nature. Hernandez argues that you could look at Ecuador's economic model and easily have a sceptical perspective arguing that the rights of nature are meaningless. Nonetheless he argues that

having declared nature as a subject of rights has awoken an enormous ecological conscience, in Ecuador and I also think it has had an international impact. 
(interview, 11.08.2015)

Martinez argues the same thing, saying that 'the legal is very important, but it is not the only thing'. She applies the same analogy of giving women or slaves rights, saying that just because there are laws against sexism or racism, it does not make it disappear from society, it needs to be internalized by the population. She is worried about the legal situation of the application of the rights of nature, but says that from a social point of view the balance is very positive, and that 'there has been an increase in the interest of topics related to nature'. She also discusses how they have led to a cognitive change, which is that they

allow you to place yourself in a much more complete context. That is, to start talking about nature not as a thing, but as a subject, is a very strong change.

(interview, 12.08.2015)

Melo concurs with this, saying that simply having certain rights in the Constitution does not solve the problem. What will solve the problem is if people appropriate the rights as a tool, and start to demand them in a political, social and law-enforcing manner.

(interview, 07.08.2015)

The rights of nature are thus represented as less of a legislative tool than an instrument to change how people act and think.

\section{The Anthropocentric Developmentalist Discourse}

The third and final discourse I have identified in my data I have named Anthropocentric Developmentalist. The informants grouped within this discourse are mostly from the government, some are from the non-profit sector. This discourse highlights how nature needs to be protected because of its many functions vital to human survival. Similar discourses are sustainable development, green growth and ecological modernization, as all are a way of having your cake and eating it too, the idea is that it is not necessary to compromise on economic growth to protect the environment (Dryzek, 2013). It is similar to the socialiststatist discourse on Buen Vivir conceptualised by inter alia Le Quang and Vercoutère (2013). I nonetheless choose to define this as a separate discourse, as it is specifically on the rights of nature. The dualist Western schema with its divisions of humans and nature is discernible in many of the articulations of this discourse. The interconnectedness of natural systems is not emphasised, nature is mostly seen as a sum of its parts, encompassing resources, goods and 
services. Ecuador is represented as a poor country with many needs, which can be taken care of by revenues from natural resources. The country is seen as having no choice but to continue to extract oil, due to both internal needs and a hegemonic international economy. Informants do not see the probability of the rights of nature leading to transformative changes as very high; they can at best provide extra leverage to already existing environmental regulation and legislation.

\section{Humans First, Then Nature}

The Anthropocentric Developmentalist Discourse is permeated by the human need for natural resources. Environmental protection is taken for granted as very important, but from an anthropocentric perspective. Francisco Prieto, then National Director of Biodiversity at the Ministry of Environment states that "the degradation of nature $[\ldots]$ obviously degrades us as well' (interview, 21.08.15). He states that nature has rights 'obviously to continue to produce the goods and services that generate and give us life in the country'. The value of the protection of nature clearly lies in its functions necessary for human survival. Law scholar Verónica Potes sees how nature is represented as less important than the human consequences of continued environmental degradation, arguing that

mother or not, what is coming is disastrous. So we need to be a bit more responsible, and here I appeal more to the responsibilities we need to have between human beings within our generations, and with future generations.

(interview, 03.08.2015)

This statement is aligned with the already mentioned notion of sustainable development, with inter-generational and intra-generational wellbeing as its focal point (Dryzek, 2013).

The importance of other rights imposed by the Correa government is another characteristic of this discourse's ontological point of departure of humans first, then nature. The rights of nature are represented as in conflict with other rights of the Ecuadorian population. Tarsicio Granizo, then head of an environmental NGO and later Minister of Environment argues that in Ecuador today 'you have the rights of nature, but you also have people's right to have what they need to have' (interview, 18.08.2015). This is elaborated upon by Enrique Torres Castro, advisor to the National Assembly (interview 19.08.2015). He states that the provision of rights to nature can only be seen within the framework of the development model of Buen Vivir. This development regime does incorporate the rights of 
nature, but it is also based on a greater provision of social rights, and other sectors have been prioritized before the rights of nature. This is in line with the socialist-statist current of Buen Vivir (Le Quang and Vercoutère, 2013). Torres justifies having to prioritise, and sees it as unlikely that the rights of nature will be developed into proper rights in the short-term, also due to the complexity of the notion. The revenues from oil extraction allows the Ecuadorian government to finance social programmes, infrastructure development and improved public education and health care. This complies with social rights of the population. The lack of implementation of the rights of nature is the price that needs to be paid at the moment. He argues that

there is a contradiction between the rights of nature and exploitation, but there is no contradiction between exploiting these resources and other axes on the level of public policies within this development model.

(interview, 19.08.2015)

\section{Good in Theory, but Hard to Comprehend}

It is the Anthropocentric Developmentalist Discourse that articulates the tensions that arise when the rights of nature with their relational ontological roots are tried incorporated into a system with a dualist ontology. Several informants express that the rights of nature are a concept that is good in theory, but hard to comprehend. Fernando Benalcázar, advisor for extractive industries believes that

as a moral and ethical principle I think it is fantastic. It is an innovative topic, it is a topic that has placed Ecuador at the forefront of the environmental debate.

(interview, 13.08.2015)

He finds it nice-sounding in principle but harder to see how it can be applied in practice. Patricio Suarez, Analyst at the Plan Nacional de Buen Vivir at the National Secretariat for Planning and Development (Senplades) (interview, 27.08.2015) states that the rights of nature are a delicate topic, because there is a lack of practice and experience. Granizo concurs, explaining that

we still do not understand how to link the principle to the legal framework, the work of public and private institutions, etc. So there is a gap still, a gap between the concept, the principle and its application. And it is gap that I do not see as closing

(interview, 18.08.2015) 
This is echoed by Suarez (interview, 27.08.2015). Reflecting upon governmental planning processes he says that 'it is quite complicated to generate projects that are coherent with the political discourse'. Potes elaborates on how she has conceptual problems with the rights of nature, but not with the idea of protecting nature itself. She finds the notion of right to restoration and existence to be strange, as

one exists without rights or with rights. Nature is there, if tomorrow we decide that nature does not have rights, it will not care.

(interview, 03.08.2015)

The confusion surrounding the rights concept is expressed by several informants. Benalcázar, the extractive industries advisor, argues that obligations come with rights, so that nature also has obligations towards man (interview, 13.08.2015). This is an interesting statement demonstrating the rights of nature's sheer overdetermination and scope of possible implications: Is giving nature rights a step towards giving it some sort of citizenship, also with obligations?

The informant from the extractive industries sums up the Anthropocentric Developmentalist Discourse by stating that 'it is very difficult to strengthen a concept of nature coming first, before the economic growth and development of the country, and before man himself' (interview, 13.08.2015).

\section{Ecuador as Small Country in International Economic System}

The second main characteristic of the Anthropocentric Developmentalist Discourse is that Ecuador is represented as a small country completely immersed in an international economic system that provides clear limits for the country's agency. This is a similar point to that found in the Anti-Capitalist Ecologist Discourse of Ecuador being a dependent country. These two discourses are the discourses most different from each other, with opposing fundamental notions and worldviews. On this point they converge however. In the Anthropocentric Developmentalist Discourse the rights of nature are represented as in a tragedy of the commons-like international game. It is impossible to apply them in a strong manner limiting extractive activities in the country, while the rest of the world continues as before, with a traditional economic development model of resource-based economic growth.

Suarez, the analyst at Senplades explains that giving nature intrinsic rights has to be a shared idea, and that Ecuador 
cannot be the only country that functions as a useful idiot I would say, because you are giving environmental services to the world, through not emitting $\mathrm{CO}_{2}$ or keeping your forests intact, but if you are the only country to do so on an international level, at some point your ideals will succumb to your real needs.

(interview, 27.08.2015)

The international systemic limitations, and the need for the rest of the world to follow suit are emphasized by several informants. Benálcazar, the Associate at the Ombudsman states that 'I would want an ideal world, but it is not possible. It is not possible that a country says 'stop exploiting' because it will not be able to survive' (interview, 08.09.2015). Granizo simply states that 'the country needs to pay its bills. It is that easy' (interview, 18.08.2015).

According to the Anthropocentric Developmentalist Discourse, Ecuador has its hands tied until other countries choose to divert its income-generating activities from natural resource extraction for the sake of the rights of nature. The international economic system provides no incentives to be more environmentally friendly and decrease resource extraction, and Ecuador has no choice but to play by its rules, until the rules are changed, for everyone. This status quo is enhanced by the many needs of the country, where 22.5 per cent of the population live below the poverty line (The World Bank, 2016). Because such a substantial amount of the national budget comes from revenues from resource extraction, there is a lack of desire from the government to change its economic model. Torres Castro says that in theory there are many reasons why oil extraction is bad, but that it is impossible to move away from it because of global economy and national needs (interview, 19.08.2015).

\section{The Rights of Nature as Environmental Regulation}

As systemic change is not seen as likely in the Anthropocentric Developmentalist Discourse, the Rights of Nature are at best represented as a stronger form of environmental regulation. Torres Castro argues that he only sees the rights of nature as possible at the moment as a stronger protection of nature (interview, 19.08.2015). Potes concurs with this, saying that she is not sure at all whether the granting of rights to nature can be a foundation for another form of development, or something different from development. What the rights of nature more realistically could imply, if there were willingness from the government she argues, is such a stronger form of environmental regulation, where licences and permits could be withdrawn in the case of environmental destruction (interview, 03.08.2015). 
Informants from government agencies highlight the comprehensive penal code (código integral penal) and how it now includes some crimes against nature, such as invading and causing destruction to protected areas, and trafficking of endangered species (Ministerio del Ambiente, no date). Tania Dávila, then Director of the Department for the Plan for Good Living in Senplades discusses a 'stronger constitutional justification' and states that

although there already were regulations and policies that encouraged a decrease of environmental impact, the fact that the rights of nature are recognized does strengthen them.

(interview, 27.08.2015)

This is echoed by Prieto at the Ministry of the Environment. He says that the strategies and regulation stemming from the Ministry of the Environment were developed from much earlier than 2008, but that the current Constitution does give them more authority (interview, 21.08.2015).

This is confirmed by the community advisor for the national oil company, who elaborates on the process to receive licences for oil drilling in an area. When asked about the extent to which they have to take the rights of nature into considerations in their activities the informant replies that 'the nature law is really quite new $[\ldots]$ within the considerations a company takes, really, I'm sincere, no (interview, 17.08.2015).

\section{Evolving Power Relations of the Discourses on the Rights of Nature in Ecuador}

Deconstructing the data and grouping it into three discourses makes the differences and similarities between them apparent. No one is outright against the rights of nature, but their scope and potential are however interpreted to be very different. All discourses agree that extraction is undesirable in itself, but necessary for the time being, illustrating the influences of non-discursive economic factors. This is in line with Lalander and Merimaa's findings of the joint premises shared by all environmental discourses in Ecuador (2018).

Ostensible ontological differences can be discerned in the different discourses. To which degree these are employed rhetorically or politically, or whether they are actually 'true' articulations based on actors' understandings of the world cannot be assessed properly in this present analysis. They are nonetheless important differential features of the discourses on the rights of nature. The first two discourses argue that nature is an interconnected whole including humans, where everything has life, and therefore should be given rights. The AntiCapitalist Ecologist Discourse has a more spiritual, immediate understanding of this relational 
co-existence, the Transformative Discourse a more intellectual approach. The Anthropocentric Developmentalist Discourse has a modernist dualist foundation for its argument that nature should be conserved to an appropriate extent, but that the needs of humans should come first.

The opportunity space existed for these discourses to co-exist and to define what can be thought of as possible. This discursive opportunity space seems to have shrunk however, as the Anthropocentric Developmentalist Discourse has increased its dominance. This can be illustrated by the sections regarding the rights of nature in Ecuador's two latest National Development plans. In the 2013-2017 plan, elements from both the Transformative Discourse and the Anthropocentric Developmentalist Discourse co-existed. In the objective 'To guarantee the rights of Nature and promote environmental sustainability globally' (Senplades, 2013a, p. 69), the rights of nature are represented as an instrument for a transformation in societal organisation globally, a feature of the Transformative Discourse. The same discourse's feature that life should be protected, regardless of whether it takes a human form or not, is also found in the same objective, which states that the rights of nature allow a 'shift in the predominant vision of Nature, usually seen solely as the provider of resources, to a more holistic Life-centred approach, in which Nature is defined as the 'place where life happens"' (Senplades, 2013b, p. 70). In the actual policies to achieve this objective however, the most visible discourse is the Anthropocentric Developmentalist, as most of these are detailed goals on environmental protection and natural resource management.

The current national development plan (2017-2021) demonstrates a dramatic shift in the representation of the rights of nature, as it is now completely dominated by the Anthropocentric Developmentalist Discourse. The intrinsic rights of nature have essentially been transformed into humans' right to a healthy environment, through intertextuality from the sustainable development trope of 'development that meets the needs of the present without compromising the ability of future generations to meet their own needs' (UN World Commission on Environment and Development, 1991). The sub-objective featuring the rights of nature is actually entitled 'Guarantee the rights of nature for current and future generations' (Senplades, 2017, p. 64, author's translation). This section is a synthesis of policy measures concerning the environment or sustainability in any way.

This development can be explained by the changing political context, i.e. the social structures and practices constituting one of the causal powers shaping discourse (Fairclough, 2003). The Citizens' Revolution was initially a more pluralist political project, receptive to different voices with the idea of creating a new Ecuador. This was echoed by the Constituent 
Assembly and the incorporation of the rights of nature into the Constitution. Another factor shaping the opportunity structures of more radical discourses regarding the rights of nature and what they might entail, was that initially many actors with a background in the environmental movement entered government and held prominent political or administrative positions (Lewis, 2016). The Citizens' Revolution also entailed ambitious plans to change the national production structure, and official discourse included the impressive discursive feat of arguing that they state had to 'use petroleum to move away from petroleum' (Suarez, interview 27.08.2015). Another contributing factor to the receptive discursive opportunity structure was the official consolidation of Buen Vivir as the new national development model. Although much can be said about the state's use of the Buen Vivir concept, it at least initially signified an openness to concepts from an indigenous worldview, as apparent in the Constituent Assembly (Espinosa, 2015).

The relationship between President Correa and civil society, particularly the indigenous and environmental movement, gradually deteriorated not least due to aggressive rhetoric regarding contentious large-scale and state-led extractive projects. During the governments of Correa, the extractive frontier has moved further into the rainforest and up the highlands. Many actors initially part of government have resigned, not least due to disagreement over the extraction-intensive development model.

The Anthropocentric Developmentalist Discourse's representation of the rights of nature as environmental regulation and anthropocentric sustainable development has become the hegemonic official discourse. It is consistently articulated by government actors and those informants closest to policy-making, and its representation of nature as resources necessary for Ecuador's economic development conditions political action. In the dialectic relationship characterising discursive and social practice, political practice has constrained which discursive representations of nature can at all be apprehended as valid, but these representations also form the basis of social and political practice. A hegemonic discourse thus functions as a self-fulfilling cycle, sustaining its dominance.

The Ecosocialist and Transformative Discourse exist as marginal antagonist counterdiscourses, but no longer constitute the same order of discourse as the Anthropocentric Developmentalist Discourse, and they are no longer able to properly assert influence over the discursive field of the rights of nature. 


\section{Conclusion}

This article argues that Ecuador's intrinsic rights of nature have remained open to interpretation since their incorporation into the 2008 Constitution, as they were a novel concept uneasily placed into a system based on a representation of nature as subject to human use, not as a right-bearing entity. They contain a surplus of meaning which competing discourses have attempted to fix in a discursive struggle. Three different discourses have constituted an order of discourse, with competing understandings of what the rights of nature might entail: The Anti-Capitalist Ecologist Discourse sees the rights of nature as a justification for continued struggle against the capitalist system. The Transformative Discourse sees the rights of nature as a potential instrument for a necessary global transformation of the human-nature relationship. The Anthropocentric Developmentalist Discourse finally sees the rights of nature as a possible form of stronger environmental regulation.

The latter discourse has always been dominant, but is now hegemonic, leaving the other two discourses at the fringes of resistance, far removed from political practice. The two latest national development plans are here used to demonstrate this, although considerable more information could have been used to validate the same tendency, including social and political practices such as the state's increased dependence on large-scale extractive projects.

The Anthropocentric Developmentalist discourse's hegemony explains why the rights of nature can co-exist alongside a continued and increased resource extraction with detrimental socio-environmental effects, as the solidified signification of the rights of nature is now anthropocentric sustainable development, of less importance than continued economic growth. 


\section{References}

Acción Ecologica. (2012). Derechos para la naturaleza: 20 tesis iconoclastas. Retrieved from http://www.accionecologica.org/naturaleza-con-derechos/articulos. [Accessed 27 June 2019]

Acosta, A. (2011). Los Derechos de la Naturaleza: Una lectura sobre el derecho a la existencia. In A. Acosta \& E. Martinez (Eds.), La Naturaleza con Derechos: De la filosofía a la política. Quito: Abya-Yala.

Akchurin, M. (2015). Constructing the Rights of Nature: Constitutional Reform, Mobilization, and Environmental Protection in Ecuador. Law \& Social Inquiry, 40(4), pp. 937-968.

Andrade, P., \& Hopp, J. Z. (2015). Ecuador: Changing biosafety frames and new political forces in Correa's government. In B. Bull \& M. Aguilar-Støen (Eds.), Environmental Politics in Latin America: Elite dynamics, the left tide and sustainable development (pp. 92-109). London: Routledge.

Ávila, R. S. (2011). El derecho de la naturaleza: fundamentos. In A. Acosta \& E. Martínez (Eds.), La Naturaleza con Derechos: De la filosofía a la política. Quito: Abya Yala.

Bebbington, A. (2012). Extractive Industries, Socio-Environmental Conflicts and Political Economic Transformations in Andean America. In A. Bebbington (Ed.), Social Conflict, Economic Development and Extractive Industry: Evidence from South America (pp. 3-26). London: Routledge.

Conaghan, C. M. (2011). Ecuador: Rafael Correa and the Citizens' Revolution. In S. Levitsky \& K. M. Roberts (Eds.), The Resurgence of the Latin American Left. Baltimore: The John Hopkins University Press.

Crabtree, J., \& Crabtree-Condor, I. (2012). The Politics of Extractive Industries in the Central Andes. In A. Bebbington (Ed.), Social Conflict, Economic Development and Extractive Industry: Evidence from South America (pp. 46-64). London: Routledge.

Cubillo-Guevara, A. P., \& Hidalgo-Capitán, A. L. (2015). El Buen Vivir Como Alternativa al Desarrollo. Perspectiva Socioecónomica, 2, pp. 5-27.

Dobson, A. (2000). Green Political Thought London: Routledge.

Doty, R. L. (1996). Imperial Encounters: The Politics of Representation in North-South Relations Minneapolis: University of Minnesota Press.

Dryzek, J. S. (2013). The Politics of the Earth: Environmental Discourses (3rd ed.) Oxford: Oxford University Press.

El Universo. (2008). Alberto Acosta renuncia como presidente de la Asamblea. Retrieved from https://www.eluniverso.com/2008/06/23/0001/8/B0D42E7B645B450BB8CC4DCD285C45E A.html. [Accessed 27 June 2019]

Espinosa, C. (2015). Interpretive Affinities: The Constitutionalization of Rights of Nature, Pacha Mama, in Ecuador. Journal of Environmental Policy \& Planning, pp. 1-19.

Fairclough, N. (2003). Analyzing Discourse: Textual Analysis of Social Research London: Routledge. 
Fairclough, N. (2010). Critical Discourse Analysis: The Critical Study of Language London: Routledge.

Fairclough, N. (2016). A dialectical-relational approach to critical discourse analysis in social research. In R. Wodak \& M. Meyer (Eds.), Methods of Critical Discourse Studies (3rd ed.). London: Sage.

Fundación Pachamama. (2010). Reconocimiento de los derechos de la naturaleza en la constitución ecuatoriana. Retrieved from https://therightsofnature.org/wpcontent/uploads/pdfs/Espanol/Fundacion_Pachamama_Experiencia_2010.pdf. [Accessed 26 June 2019]

Gudynas, E. (2009). El mandato ecológico: Derechos de la Naturaleza y políticas ambientales en la nueva Constitución Quito: Ediciones Abya-Yala.

Hay, I. (2010). Qualitative Research Methods in Human Geography (Third ed.) Oxford: Oxford University Press.

IMF. (2017). Ecuador. World Economic Outlook Database. Retrieved from https://www.imf.org/external/pubs/ft/weo/2017/02/weodata/weoselser.aspx?c=248\&t=1. [Accessed 5 December 2017]

Jørgensen, M., \& Phillips, L. (2002). Discourse Analysis as Theory and Method London: Sage.

Kauffman, C. M., \& Martin, P. L. (2017). Can Rights of Nature Make Development More Sustainable? Why Some Ecuadorian lawsuits Succeed and Others Fail. World Development, 92, pp. 130-142.

Kotzé, L. J., \& Calzadilla, P. V. (2017). Somewhere between Rhetoric and Reality: Environmental Constitutionalism and the Rights of Nature in Ecuador. Transnational Environmental Law, 6(3), pp. 401-433.

Laclau, E., \& Mouffe, C. (2014). Hegemony and Socialist Strategy: Towards a Radical Democratic Politics London: Verso.

Lalander, R. (2014). The Ecuadorian Resource dilemma: Sumak Kawsay or development? Critical Sociology, pp. 1-20.

Lalander, R., \& Cuestas-Caza, J. (2017). Sumak Kawsay y Buen-Vivir en Ecuador. In A. D. V. Delgado (Ed.), Conocimientos ancestrales y procesos de desarrollo: Nacionalidades Indigenas del Ecuador (pp. 30-64). Loja, Ecuador: Universidad Técnica Particular de Loja.

Lalander, R., \& Merimaa, M. (2018). The Discursive Paradox of Environmental Conflict: Between Ecologism and Economism in Ecuador. Forum for Development Studies, 45(3), pp. 485-511.

Larrea, C., \& Warnars, L. (2009). Ecuador's Yasuní-ITT Initiative: Avoiding emissions by keeping petroleum underground. Energy for Sustainable Development, 13(3), pp. 219-223.

Le Quang, M., \& Vercoutère, T. (2013). Ecosocialismo y Buen Vivir: Diálogo entre dos alternativas al capitalismo Quito: Editorial IAEN. 
Lewis, T. L. (2016). Ecuador's Environmental Revolutions:. Ecoimperialists, Ecodependents, and Ecoresisters Cambridge. Massachusetts: The MIT Press.

Melo, M. (2009). Los Derechos de la Naturaleza en la nueva Constitución ecuatoriana. In A. Acosta \& E. Martinez (Eds.), Derechos de la Naturaleza: El futuro es ahora. Quito: Abya-Yala.

Ministerio del Ambiente. (no date). Los delitos ambientals en el nuevo código orgánico integral penal ecuatoriano. Retrieved from http://sib.ambiente.gob.ec/file/TVS/6.-Raúl\%20Guaña\%20Delitos\%20Ambientales\%20Código\%20Penal.pdf [Accessed 27.03.2016].

Moore, J., \& Velásquez, T. (2012). Sovereignty negotiated: anti-mining movements, the state and multinational mining companies under Correa's '21st Century Socialism'. In A. Bebbington (Ed.), Social Conflict, Economic Development and Extractive Industry: Evidence from South America (pp. 112-133). London: Routledge.

Neumann, I. B. (2001). Mening, materialitet, makt: En innføring i diskursanalyse Bergen: Fagbokforlaget.

Novo, C. M. (2014). Managing Diversity in Postneoliberal Ecuador. The Journal of Latin American and Caribbean Anthropology, 19(1), pp. 103-125.

Payne, A., \& Phillips, N. (2010). Development Cambridge: Polity Press.

Radcliffe, S. A. (2011). Development for a postneoliberal era? Sumak kawsay, living well and the limits to decolonisation in Ecuador. Geoforum, 43(2), pp. 240-249.

República del Ecuador. (2008). Constitución Política del Ecuador Montecristi: Asamblea Nacional Constituyente.

Sánchez-Parga, J. (2014). Alternativas virtuales vs. cambios reales Quito: Centro Andino de Acción Popular -CAAP-.

Senplades. (2013a). National Plan for Good Living. Summarized Version. Quito: Senplades.

Senplades. (2013b). Plan Nacional de Desarrollo / Plan Nacional para el Buen Vivir 2013-2017. Quito, Ecuador: Senplades.

Senplades. (2017). Toda una Vida: Plan Nacional de Desarrollo 2017-2021. Quito, Ecuador: Senplades.

Silverman, D. (2010). Doing Qualitative Research (3rd ed.) London: Sage.

Stavrakakis, Y., Horwarth, D., \& Norval, A. (2000). Discourse Theory and Political Analysis Manchester: Manchester University Press.

Tanasescu, M. (2013). The rights of nature in Ecuador: the making of an idea. International Journal of Environmental Studies, 70(6), pp. 846-861.

The World Bank. (2016). Data: Ecuador. Retrieved from http://data.worldbank.org/country/ecuador [Accessed 04.05.2016].

U.S. Energy Information Administration. (2017). Ecuador: Analysis. Retrieved from https://www.eia.gov/beta/international/analysis.cfm?iso=ECU. [Accessed 5 December 2017]

UN World Commission on Environment and Development. (1991). Our Common Future. 
Villalba-Eguiluz, C. U., \& Etxano, I. (2017). Buen Vivir vs Development (II): The Limits of (Neo)Extractivism. Ecological Economics, 138((2017)), pp. 1-11. 